\section{Effects of daylight design features on visitors' satisfaction of museums}

\author{
Sevkiye M Kaya and Yasemin Afacan
}

Indoor and Built Environment 2018, Vol. 27(10) 1341-1356 (C) The Author(s) 2017 Article reuse guidelines: sagepub.com/journalspermissions DOI: $10.1177 / 1420326 \times 17704028$ journals.sagepub.com/home/ibe @SAGE

\begin{abstract}
This study evaluates daylight performance in an art museum in İstanbul, Turkey to analyse the effects of daylight design features on visitors' satisfaction in art museums. The study is based on users' data obtained through a survey and daylight simulation achieved by Autodesk 3D's Max 2014. A three-part questionnaire was conducted with 100 participants in overcast- and clear-sky conditions to rate visitors' satisfaction with the museum and their importance level of daylight design issues in museums. The museum's daylight illuminance data were measured on a scaled model by a computer simulation program. The statistical results and simulation renderings show that daylight design is a multiparameter task. There are statistically significant correlations between visual comfort and visitor satisfaction. The study finds two essential daylight considerations for a practical guide to promote healthy and effective daylight use in museums: (i) that certain design aspects in a museum, such as location, window size and window distance from partitions or displays, are important regardless of weather conditions and that (ii) glare prevention from openings such as windows and skylights is also a crucial aspect in visual comfort.
\end{abstract}

\title{
Keywords
}

Daylight design, Daylight control strategies, Visual comfort, Sustainability

Accepted: 12 March 2017

\section{Introduction}

With growing attention on improved living standards, sustainability and health issues, demand is rising for better visual quality in buildings, including art museums. Most museum designers and architects have introduced distinctive daylight control strategies and effective daylight design factors that are characterized by environmental friendliness, sustainability, collection safety, visitor satisfaction and effective interior design. Applying daylight in buildings has been proven to increase social, environmental and economic performances compared to standard construction with artificial lighting only. Several studies suggest that daylight application in buildings can optimize lighting ambiance and reduce glare discomfort. ${ }^{1}$ Building studies provide a comparison of daylight performances and suggest better uses of daylight. To see 'what is working' and 'what is not' regarding specific daylight design strategies, certain technologies should be implemented. Many studies focus on evaluating daylight qualities and daylight design strategies in various interior spaces. ${ }^{2}$ Proper daylight design strategies are essential in art museums to protect the collections; however, a user-centred approach regarding visual comfort and user satisfaction is lacking in the current design literature.

Daylight design in museums is complex for two reasons: first, damage can be caused by daylight exposure to different objects with different sensitivity levels, and second, designers lack user requirement knowledge.

Department of Interior Architecture \& Environmental Design, Faculty of Art, Design and Architecture, Bilkent University, Bilkent, Ankara, Turkey

\section{Corresponding author:}

Sevkiye M Kaya, Department of Interior Architecture \& Environmental Design, Faculty of Art, Design and Architecture, Bilkent University, TR-06800 Bilkent, Ankara, Turkey.

Email: sevkiye.kaya@bilkent.edu.tr 
It is thus necessary to understand museums as special interior spaces. This study aimed to overcome the abovementioned gaps by (i) conducting a user requirement survey in which existing daylight performance evaluation indicators were utilized to investigate visitor satisfaction, (ii) determining the importance levels of daylight design parameters for an efficient daylight environment within museums, (iii) simulating daylight illuminance, and finally, (iv) comparing user data with simulation analyses.

\section{Daylight and user satisfaction}

Daylight is a significant source of energy and plays an important role in the visual environment. Numerous studies examine the role of daylight in public spaces. In many buildings, designers are encouraged to develop daylight strategies to reduce energy consumption by utilizing the environmental effects of artificial lighting as well as cooling demands of heating, ventilation and air conditioning systems. Solar radiation is the most important factor (among others) in overall thermal transfer value. ${ }^{3}$ The advantage of daylight on visual effects makes daylight design irresistible in art museums, and the importance of daylight should be analysed according to the museum's structure and function. ${ }^{4}$ Most objects in art museums are related to the visual arts, and thus mainly appeal to the sense of sight. For this reason, an art museum aims to create an interior space that enhances human perception and visual environmental qualities. ${ }^{5}$ Therefore, daylight design within art museums is a very important issue that should be handled with care for the sake of museums' 'display' and 'protection' functions.

A review of the literature shows that daylight (or the lack of it) has significant psychological effects on humans. Flynn et al. ${ }^{6,7}$ report that lighting variations affect users' behaviours and suggest a guide to procedures for measuring different subjective impressions in daylight. According to Cheung and Chung's study, ${ }^{8}$ daylight is defined as a vehicle that influences users' understanding of the environment, dominates the information given by the environment's visual field and affects well-being. A number of studies report that access to a window with daylight and an outside view are key parameters for users' satisfaction, regardless of the type of built environment. ${ }^{9-12}$ Heerwagen and Heerwagen ${ }^{13}$ surveyed occupants in a US office in winter and summer and highlight the importance of daylight for visual health and psychological comfort. According to Veitch and Robert's ${ }^{14}$ results, most university students work better in daylight conditions than in artificial light. Cheung and Chung ${ }^{8}$ emphasize that users' preference for daylight is inevitable in residential indoor environments. A qualitative and quantative survey with Austrian workers report that daylight in office buildings can be aligned with high levels of well-being and user satisfaction. ${ }^{15}$

Architectural daylighting in art museums can be defined as both an art and a science, requiring an understanding of not only the physical properties of natural and artificial light sources but also the visual effect that create 'space'. In addition to aesthetic and illustration qualities, daylight design is important because of its energy conservation benefits and opportunities for various light qualities and colour-rendering impacts. With these advantages, daylight enhances pleasantness, satisfaction and visual appearance in museums. According to Steemers, ${ }^{16}$ the relationship between daylight and design is inseparable in museums. Kim and $\mathrm{Kim}^{17}$ explored daylight performances of exhibition spaces in museums and highlight the importance of toplight and its different shapes for user satisfaction. Kim and Chung ${ }^{4}$ conducted daylight simulations and emphasize daylight's energy-conservation benefits and the opportunities for utilizing various light qualities and colour-rendering effects in museums. According to this study, using daylighting analysis software and comparing simulations with real environmental data can be integrated into architectural design to increase user satisfaction. ${ }^{4}$ Mundo-Hernández et al. ${ }^{18}$ conducted a post-occupancy survey in an art gallery in Mexico. The findings show that good availability of daylight makes an art gallery comfortable and increases its interior environmental quality.

Thus, visitor satisfaction in museums can be defined as a psychological state, with dissatisfaction like 'gap' felt during the consumption experience and resulting from the disconfirmation of the visitor's prior feelings and expectations about museum exhibits. ${ }^{19}$ Expectations are viewed as the primary measurement of visitors' satisfaction, and if the consumption experience exceeds these expectations, the person would be satisfied. Within the framework of the current study, satisfaction is defined as the visitor's experience of visual comfort parameters in interior spaces, such as levels of eye adaptation, glare, balanced daylight, high-contrast illumination and daylight intensity.

\section{Visual experience, visual comfort and daylight}

Currently, supporting richer visitor experiences and enhancing visual comfort are big challenges in museums. Visitors should be able to see, manipulate and interact with artwork, and more importantly, to achieve repeat visits, museums must attract a visitor's attention to its subject matter and ensure satisfaction. ${ }^{4}$ Visual comfort is an important satisfaction parameter in an art museum, contributing to a comfortable and 
satisfying experience. Thus, during the design process, many architects have tried to support richer visitor experiences by enhancing the effectiveness of display methods. According to Cannon-Brookes ${ }^{20}$ daylight is capable of changing the quality of our lives, for better or for worse. He reports that inside a gallery, daylight combines the twin virtues of diffusion and orientation of historical appropriateness and colour renderings, to which all other sources are compared. Escuyer and Fontoynont ${ }^{21}$ investigated office workers' visual experiences and report that workers perceive $300 \mathrm{~lx}$ natural light illuminance as pleasant. Under the same artificial light illuminance, the subjects had more intense visual experiences but they were unpleasant and visually uncomfortable. In Cheung and Chung's study, ${ }^{8}$ general brightness and an outside view were the most preferred comfort factors while evaluating an interior residential room. Moreover, a pleasant view increases tolerance for glare. Over the last decade, most researchers have emphasized that users of sustainable buildings and green interiors are more visually comfortable compared to those in conventional buildings. ${ }^{22}$ Sarbu and Sebarchievici ${ }^{23}$ assessed buildings' indoor environmental quality and find that visual comfort is also related to the thermal environment, which affects performance and productivity. Furthermore, the visual experience and visual comfort level varies according to the task performed. 'In an attempt to meet visual comfort criteria, we shall take into account the environment (material and people) and the task at the hand in order to specify the notion of visual atmosphere'. According to Anthierens et al., ${ }^{5}$ if there is visual discomfort, then there is imbalanced light, uncomfortable backlighting, local glare, high contrast zones and inadequate lighting intensity. These factors cause problems such as loss of productivity, increase in stress levels, early tiredness and adaptation problems. Therefore, visual experience and comfort should be considered carefully and simultaneously during the design, construction and occupation phases of all buildings, including art museums.

\section{Windows, glare and discomfort}

The above studies show that daylight provides many benefits to building design and building users, such as improved health and well-being, increased lighting quality and increased user satisfaction. However, daylight's dynamic structure should be handled with care. Planning for daylight is not simply a matter of using large areas of window glazing, as this approach would only create problems of glare and discomfort. Instead, daylight design must be an integral part of the overall design process.

A design strategy to ensure good daylight conditions in art museums should consider the following features: daylight availability and sky conditions, the building site and any obstructions related to visual connection to the outdoors, the form and function of the building, interior planning and design, protection issues, window and façade design (size and divisions of the windows), innovative daylight techniques and testing the design strategy. ${ }^{24}$ Innovative light-control techniques can include light-directing louvers, light shelves, movable shading systems, mirrored systems, prismatic glazing and light pipes. ${ }^{6}$ A successful light-control technique also requires optimizing competing design aspects, such as façade layout, space configuration and lighting system. Examples of some daylight control systems are as follows: sizing the windows to provide view, daylight and some solar gain; using controllable and moveable shading devices such as Venetian blinds; reducing the contrast between the window and its wall by using light walls; positioning computer work spaces perpendicular to windows; partitioning large, open-plan spaces and orienting the building to daylight. ${ }^{6}$ Sutter et al. ${ }^{25}$ tested Venetian blinds in offices and find that the type of shading system control is important. Remotely controlled black Venetian blinds were used three times more often than manually controlled fabric blinds.

Daylight varies in intensity, colour and direction over time. A major design problem with daylight is the rapid decrease in daylight levels with increased distance from a window, leading to parts of a room appearing gloomy. Ongoing innovative developments of new glazing technologies and shading devices allow for a large variety of new window and façade solutions. In this manner, one of the most important aspects of daylight design is identifying the optical glazing properties that provide adequate daylight levels while avoiding glare and excessive heat gains. Glare causes visual discomfort which could be the result of a very bright object in a person's field of view. Minor levels of glare could be irritating but can usually be neglected; however, high levels of glare could interrupt performance or even cause risk of injury as people move around unfamiliar spaces. Hopkinson ${ }^{26}$ finds that glare from daylight is more tolerated than glare from artificial light. Therefore, one very important aim of daylight design is to control the range of brightness likely to be experienced by a building user. A design that aims for a sufficient amount of daylight within interior spaces may incorporate large glazing areas, which can cause excessive glare. Most studies on glare evaluate discomfort by having participants directly view the glare source rather than focus on a work task. ${ }^{27}$ However, Wienold and Christoffersen ${ }^{28}$ develop a new glare prediction model by investigating user perception of solar shading systems regarding glare in a laboratory. Their study provides a great potential for an improved understanding of the relationship between 
measured lighting conditions and user response. ${ }^{28}$ According to these authors, window size and viewing direction are key issues for different aspects of glare, discomfort, energy demand and daylight control strategies. ${ }^{28}$ Kilic and Hasirci's study ${ }^{11}$ supports this finding in a library context and highlights that tolerance to glare and discomfort are also closely related to the amount of time spent in the area.

\section{Methodology}

The current study is based on user data obtained through a questionnaire and by daylight simulation data obtained by Autodesk 3D's Max 2014. Over the last decade, most daylight analyses have been conducted by computer simulation models that represent the lighting environment under clear- and overcast-sky conditions. However, Kim and Chung's ${ }^{4}$ findings suggest that there are large differences between real sky conditions for scale model measurements and the CIE sky conditions for computer simulations. Moreover, subjective measurements and more user-centred models are important. Therefore, this study used both a questionnaire for subjective findings and computer simulation analyses for objective findings. The simulations were generated after the 3D model designs of the case building were completed. The following sections explain how users and case building were selected and how the simulation data were generated accordingly.

\section{Research objectives}

The study has two research objectives. The first aims to determine factors that increase visitor's satisfaction within an art museum. The questions asked in the survey were based on a literature review and sought input on the following subjects: daylight availability, controlled daylight intake, size and division of windows, visual connection to the outdoors, glare prevention from windows and objects) and filtration of excess light exposure (UV, infrared, etc.). The second objective aims to elucidate visitor's importance levels for visual comfort in a museum. Windows, skylights, shading systems, reflected-light techniques, local glare prevention, imbalanced light prevention, inadequate daylight intensity prevention, visual obstruction prevention and visual connection with the outdoor environment are the factors explored in the importance rating section of the questionnaire.

\section{Sample and site}

A total of 100 people participated in the study. The survey was conducted on two separate days, one day under clear skies and the other under overcast skies.
Therefore, participant availability for both sessions was the primary criterion when selecting the questionnaire subjects. The second criterion was subject familiarity with the museum. The authors preferred subjects to be familiar with the museum. Thus, 60 of the 100 participants were recruited through email invitations to second-year undergraduate architecture students at Özyegin University in İstanbul, Turkey, who were asked to visit a museum as a research assignment. Only 60 of the 200 invited students were available for both sessions and agreed to participate in the study. The remaining 40 participants were recruited from visitors already at the museum the day of the first session and were chosen because of their agreement to be available for the second session as well (when it was a clear day, authors called everyone up and said the study was happening that day). Therefore, all the 100 participants were physically in the museum's gallery space during both sessions and answered the survey questions. Each participant was also asked to sign a consent form to satisfy ethical procedures. The first session, 20 January 2015, had overcast skies and the second session, 4 March 2015, had clear skies. Any negative effects of this repeated-measures design, that is, the risk of carry-over effects from one survey to the next, was overcome by the break between sessions. None of these participants needed institutional care and none had mental disabilities. Participant demographics are shown in Table 1.

Table 1. Percentages related to participant demographics.

\begin{tabular}{lcc}
\hline Participant characteristics & Percentages & Frequencies \\
\hline Gender & 55 & 55 \\
$\quad$ Female & 45 & 45 \\
$\quad$ Male & & \\
Age group & 60 & 60 \\
20-35 years & 28 & 28 \\
36-50 years & 12 & 12 \\
51-65 years & - & - \\
Over 65 years & & \\
Education level & 69 & 69 \\
High school & 24 & 24 \\
University & 3 & 3 \\
Graduate degree & 4 & 4 \\
Post-graduate degree & & - \\
Visit frequency & - & - \\
Twice a week & - & 73 \\
Once a week & 19 & \\
Twice a month & 73 & \\
Once a month & & \\
Less often & &
\end{tabular}




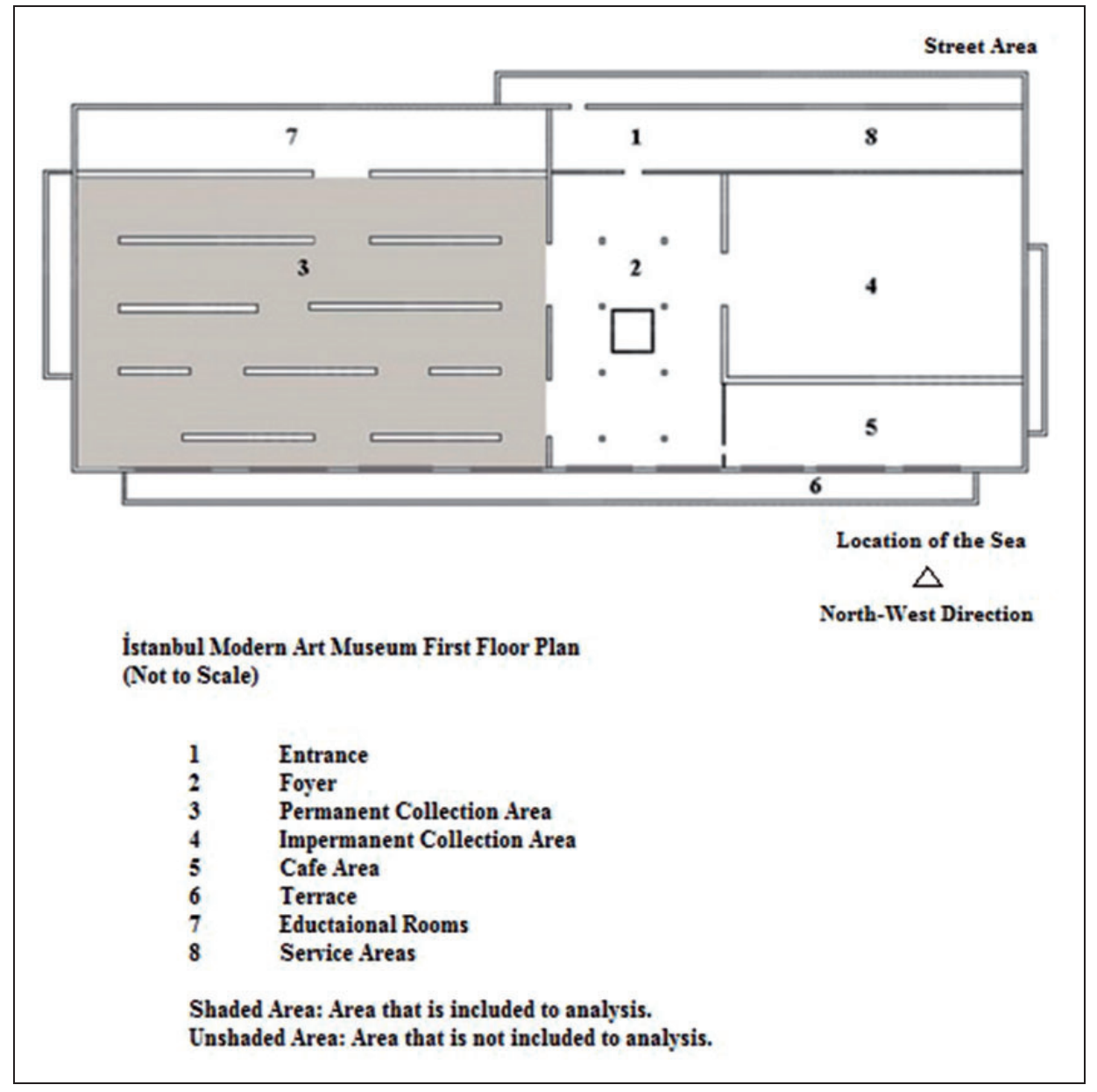

Figure 1. İstanbul Modern Art Museum first-floor plan.

İstanbul Modern Art Museum, which opened in 2004 as the first Turkish museum of contemporary art, was selected as the case building. The museum is situated on the shores of the Bosporus, and faces the historical peninsula of Istanbul. The building is $8000 \mathrm{~m}^{2}$ floor area over two storeys. It is a former warehouse. In addition to the exhibition rooms, it has a library, restaurant, terrace café, gift shop, movie theatre, seminar rooms, education rooms and service areas. This museum was selected as the case building for the following reasons: (i) daylight in the exhibition areas, (ii) convenient city-centre location and (iii) visual connection with the outside (see Figures 1 and 2).

\section{Procedure}

A questionnaire was developed specifically related to the İstanbul Modern Art Museum. The survey took approximately 3 to $5 \mathrm{~min}$ to complete and was conducted with each participant individually. The survey involved three parts (see Appendix 1). The first part included demographic information visit frequency.

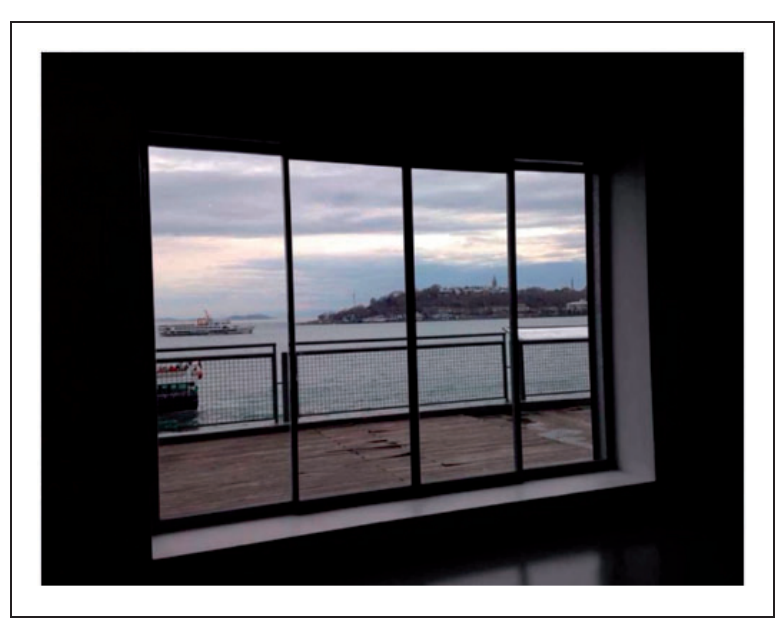

Figure 2. View through the window of the permanent collection area to the sea.

In the second part, participants were asked to rate their satisfaction level with the museum's daylight design features on a five-point Likert-type scale, ranging from 'poor' to 'excellent'. This part of the survey 


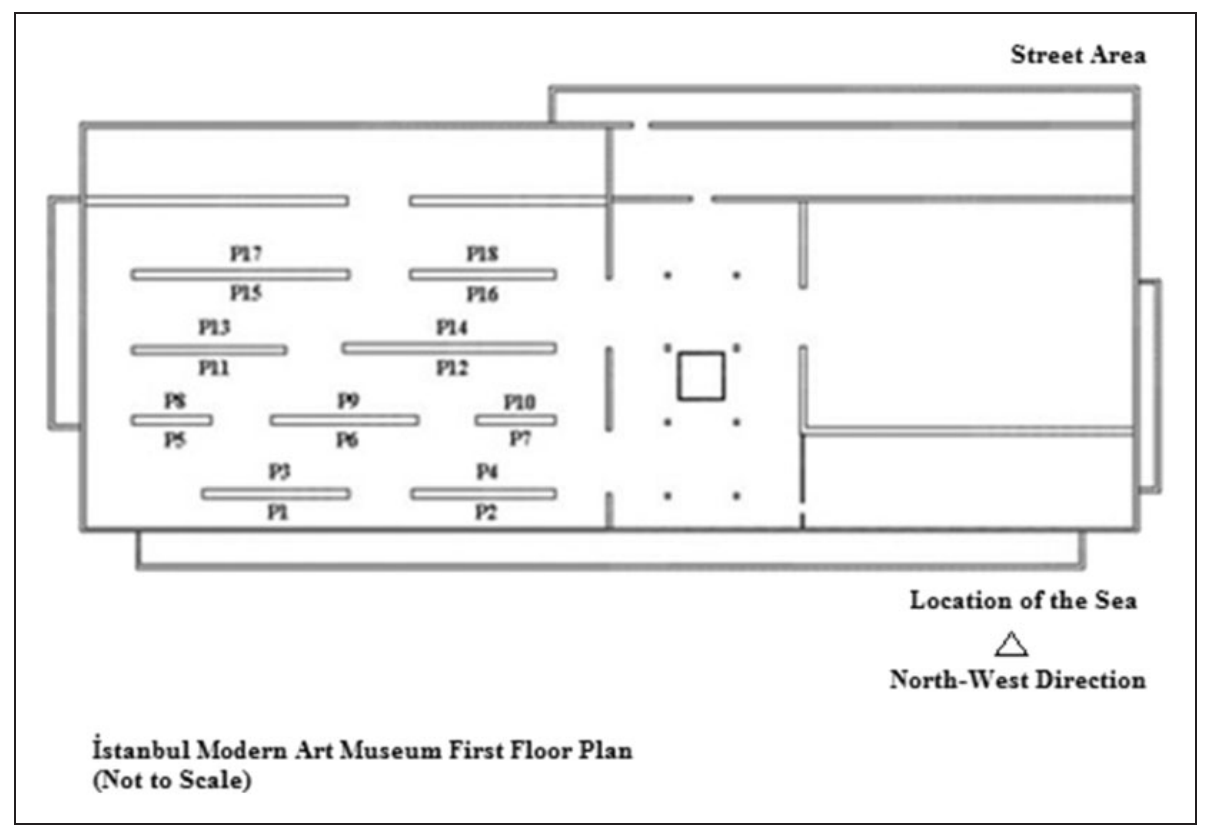

Figure 3. Eighteen light meter locations as represented by 18 points within the museum.

included 11 questions: The first two questions focused on daylight in the museum's interior space (availability and controlled daylight intake). The third and fourth questions were related to the museum's outdoor connection through windows and other visual features. The next six questions were designed to capture the visitor's visual experiences around glare, colour rendering, daylight distributions and thermal comfort conditions. The last question of the second part assessed overall visitor's satisfaction. The third part of the survey assessed participant importance levels for each sub-study, considering daylight design features of art museums in general. First, the level of importance of windows and skylights as major daylight design features was explored, ${ }^{24}$ then two questions focused on innovative control strategies such as shading systems (interior and exterior) and reflected-light techniques (light shelves). Next, four importance questions were categorized under interior visual comfort around daylight distribution, glare and intensity. Furthermore, since visual comfort varies according to the visual connection to the outdoors, visitor's thoughts on neighbouring building surfaces and visual obstructions were also queried. Energy conservation and sustainability were considered as a last question. This part also included an unstructured interview part to allow participants to freely provide their thoughts on what should be done to enhance visual comfort and satisfaction while using daylight in museums.

The computer simulation was designed by eliminating artificial light. The lighting source was taken as daylight, obtained from indirect and direct sunlight entering the building through doors and windows.
With this method, daylight availability can be observed and analysed without other light sources influencing the interior space. The simulations were generated after $3 \mathrm{D}$ model generation of the selected case study building was completed. To keep the simulation as accurate as possible, the modelling ensured that, other than windows and doors, there were no gaps where daylight could leak into the interior. ${ }^{29}$ For the daylight analysis of this study, 18 specific points were selected at which to place light meters (Figure 3). The viewing direction is shown in Figure 3. Eighteen light meters were placed $132.5 \mathrm{~cm}$ from the ground, at standing eye-level, which is the reference point for what is defined as horizontal. ${ }^{30}$ Therefore, the illuminance level values given in the Results section for these 18 specific points are for horizontal illuminance. Daylight analyses on these 18 points were conducted at 10:00 h, 12:00 h, 14:00 h and 16:00 h for both condition types.

\section{Results}

\section{Survey findings}

Correlations for satisfaction with museum experiences. To analyse the obtained data from questionnaires, the Statistical Package for the Social Sciences (SPSS) 15.0 was used and correlation diagrams were constructed. All correlation coefficients are significant at a $95 \%$ confidence level and show positive correlations for the clear- and overcast-sky conditions (see Appendix 2 for the correlation tables). The correlation results show that while there is effective daylight intake with support of the control strategies, the 
colour-rendering effects have significant correlation values in terms of overall visitor's satisfaction level for both weather conditions. In analysing participants' ratings of the 11 satisfaction items in the clear-sky condition, the largest association occurs between the prevention of glare from windows and prevention of glare from the neighbouring building structures (0.808). Direct sun penetration has the second largest overall association with daylight availability $(0.681)$. The second largest correlation appeared between overall satisfaction and direct sun penetration (0.623) and daylight availability (0.613). Overall satisfaction is also moderately correlated with control systems of daylight intake (0.528) and colour-rendering surfaces (0.506). The numbers in parentheses represent the correlation values, indicating the association level between the two items. A correlation coefficient of 0.5 would indicate a moderate relationship between the two variables, whereas a correlation of 1.0 indicates a perfect association. ${ }^{31}$ In this respect, glare from windows has the largest overall association with prevention of glare from neighbouring building structures in the clear-sky condition (see correlation Tables 4 and 5 in Appendix 2 for the clear-sky condition).

For the overcast-sky condition, the prevention of glare from windows has again the largest overall association with prevention of glare from neighbouring building structures $(0.846)$. The second largest association occurs between direct sun penetration with daylight availability (0.724). There are moderate correlations between the control systems for daylight intake and the prevention of glare from neighbouring building structures (0.570) and the prevention of glare from windows. Other moderate correlations occur between size and divisions of windows and daylight availability (0.509) and direct sun penetration (0.441). Different from the clear-sky condition, overall satisfaction is moderately correlated with colour-rendering surfaces (0.523) (see correlation Tables 6 and 7 in Appendix 2 for the overcast-sky condition).

Correlations for importance levels. Correlation analyses of participant ratings on the 11 items in terms of their importance levels show that windows and skylights are very strongly correlated with each other for both weather conditions, which is 0.903 for the clearsky condition and 0.907 for the overcast-sky condition. Shading systems are moderately correlated with windows (0.601) and skylights (0.593) for the clear-sky condition. However, for the overcast-sky condition analysis, there are slightly different values because of the different intensity of daylight levels. For the overcast-sky condition, shading systems are moderately correlated with windows (0.498) and skylights $(0.555)$. Prevention of local glare and adequate daylight intensity has a moderate correlation $(0.55)$ with the clear-sky condition, whereas it is strongly correlated in the overcast-sky condition (0.805).

These correlation analyses support the literature and show that the outdoor view is significantly positively related with visitors' overall satisfaction in art museums. Since daylight is related to the outside environment, there is a link between interior visual environmental quality and visual connection to the outdoors. Obstructions such as buildings or foliage can be unfavourable to interior visual environmental quality, and glare caused by the outside environment can be a serious issue. The results of this study were positively affected by the attractive location of the selected art museum: near the Marmara Sea with a view of the Bosporus and historical spaces such as Topkap1 Palace and Hagia Sophia Mosque. Furthermore, the correlations emphasize that visitors give high importance to daylight design elements like windows and skylights that are closely associated with daylight control strategies. Both architectural design elements and control strategies are important factors to allow efficient visual comfort for visitors, and they should be considered together.

The unstructured part of the survey highlighted the importance of the daylight experience for visitors. Sixty of the 100 participants in the clear-sky condition stated that when the control strategies and effective daylight design methods are applied in that type of weather situation, they are more visually comfortable and satisfied. Seventy of the 100 participants in the clear-sky condition noted that they have a better museum experience on sunny days. For the overcast-sky condition, $65 \%$ of participants highlighted that control systems and effective daylight design methods offer them a better museum experience and better visual environmental quality. Fifty-five per cent stated that they like a connection with the outdoor environment in a museum. However, 28 per cent were opposed to an outdoor connection even though they enjoyed the view from İstanbul Modern Art Museum, as they felt the outside view distracted them from the museum's exhibitions. They wished there were some control of the outside view. İstanbul Modern Art Museum only has windows in the first floor exhibition zone, and that the outside view mostly benefits the café area. Our findings shows that 85 of the 100 participants were aware of energy conservation through daylight integration and very sensitive to the necessity of protecting the art museum's collections from light damage.

\section{Simulation findings and discussions}

The daylight simulation for this study is a computerbased calculation of the amount of daylight inside the 
selected art museum. The program is 3D Max by Autodesk, which is capable of simulating the daylight of a specific place in the daylight condition of a certain date, time zone and location (longitude and latitude) with compass orientation and a real-weather data base (Energy Plus Weather File). The value of the calculated light is in lux. The simulation program can also set altitude and azimuth related to realweather databases, which calculate the work plane that is set through the $3 \mathrm{D}$ model. The light meter, which calculates illuminance levels in a space, was created in the $3 \mathrm{D}$ space at the workplane position at eye level. It covers the entire room area and has a relatively coarse subdivision. The results of the daylight simulation analysis and the 3D rendering perspectives show that there is a significant difference in daylight conditions between clear-sky and overcast-sky conditions at the 18 points for 10:00 h, 12:00 h, 14:00 h and 16:00 h. For both conditions, point 2 has the peak value of illuminance level and point 1 has the second highest illuminance level for all analysed hours (Tables 2 and 3). These two points had very high illuminance values compared to other points as they were closest to the windows and unobstructed by partitions. Since there was a decrease in illuminance levels at points farther away from windows, the museum used more artificial light to provide effective light for visitor visual comfort.

Table 2. Illuminance levels based on the simulation values (lux): clear-sky condition.

\begin{tabular}{llrrrr}
\hline $\begin{array}{l}\text { Illuminance } \\
\text { levels }\end{array}$ & & & & & \\
\hline Lux (1x) & Points & $10: 00 \mathrm{~h}$ & $12: 00 \mathrm{~h}$ & $14: 00 \mathrm{~h}$ & $16: 00 \mathrm{~h}$ \\
& P2 & 360.59 & 207.74 & 208.81 & 285.24 \\
& P3 & 0.00 & 0.00 & 0.00 & 0.00 \\
& P4 & 0.00 & 0.00 & 0.00 & 0.00 \\
& P5 & 44.67 & 24.43 & 16.46 & 17.76 \\
& P6 & 0.43 & 0.32 & 0.32 & 0.59 \\
& P7 & 18.19 & 13.99 & 15.82 & 19.16 \\
& P8 & 31.65 & 17.98 & 11.73 & 12.60 \\
& P9 & 0.00 & 0.00 & 0.00 & 0.00 \\
& P10 & 2.58 & 3.77 & 4.96 & 4.84 \\
& P11 & 4.95 & 5.60 & 4.52 & 3.88 \\
P12 & 3.22 & 3.55 & 3.99 & 4.09 \\
& P13 & 8.07 & 8.39 & 6.67 & 5.81 \\
P14 & 6.16 & 5.38 & 5.49 & 6.14 \\
P15 & 0.22 & 0.10 & 0.10 & 0.10 \\
P16 & 0.322 & 0.22 & 0.22 & 0.322 \\
P17 & 1.30 & 0.75 & 0.75 & 1.07 \\
P18 & 4.30 & 2.37 & 2.15 & 3.12 \\
\hline
\end{tabular}

According to the daylight simulation data, from 10:00 hours to 16:00 hours, there was a decrease in illuminance levels for most points (see Figures 4 and 5). Although the real environment was an art museum building with natural and effective artificial light, the computer simulation was done only with natural light because this research explored only the daylight and its relationship with visitor comfort and experience. Further, some vertical museum displays decrease the daylight levels. Because of daylight's characteristics, its illuminances across the work plane exhibit large variations both spatially and temporally. This situation means that daylight illuminances typically decrease rapidly with increasing distance from windows. Further, daylight illuminances at a point can vary greatly from one moment to the next based on sky conditions. ${ }^{32}$

Table 2 includes the illuminance level data for the clear-sky condition, and Table 3 includes the illuminance level data for the overcast-sky condition. The illuminance levels reflect the vertical illuminance obtained from the 18 lux meters mentioned at point 1 , and point 2 had the maximum illuminance levels. Since these points were close to windows and unobstructed, they benefit from daylight more than the other points selected. These results for both points are the same under both sky conditions. The only difference that illuminance levels for the overcast sky are lower than for the clear sky, but point 1 and point 2 still had the

Table 3. Illuminance levels based on the simulation values (lux): overcast-sky condition.

\begin{tabular}{lrrrrr}
\hline $\begin{array}{l}\text { Illuminance } \\
\text { levels }\end{array}$ & & & & & \\
\hline Lux (1x) & P1 & 77.29 & 77.29 & 77.29 & 77.29 \\
& P2 & 212.05 & 212.05 & 212.05 & 212.05 \\
& P3 & 0.00 & 0.00 & 0.00 & 0.00 \\
& P4 & 0.00 & 0.00 & 0.00 & 0.00 \\
& P5 & 8.72 & 8.72 & 8.72 & 8.72 \\
& P6 & 1.29 & 1.29 & 1.29 & 1.29 \\
& P7 & 2.26 & 2.26 & 2.26 & 2.15 \\
& P8 & 5.60 & 5.60 & 5.60 & 5.60 \\
& P9 & 0.00 & 0.00 & 0.00 & 0.00 \\
& P10 & 3.88 & 3.88 & 3.88 & 3.88 \\
& P11 & 0.97 & 0.97 & 0.75 & 0.75 \\
& P12 & 0.75 & 0.75 & 0.75 & 0.54 \\
& P13 & 1.40 & 1.403 & 1.18 & 1.18 \\
& P14 & 1.30 & 1.30 & 1.30 & 1.30 \\
& P15 & 0.11 & 0.11 & 0.11 & 0.11 \\
P16 & 0.11 & 0.11 & 0.11 & 0.11 \\
P17 & 0.02 & 0.02 & 0.02 & 0.02 \\
P18 & 0.22 & 0.22 & 0.22 & 0.65 \\
\hline
\end{tabular}




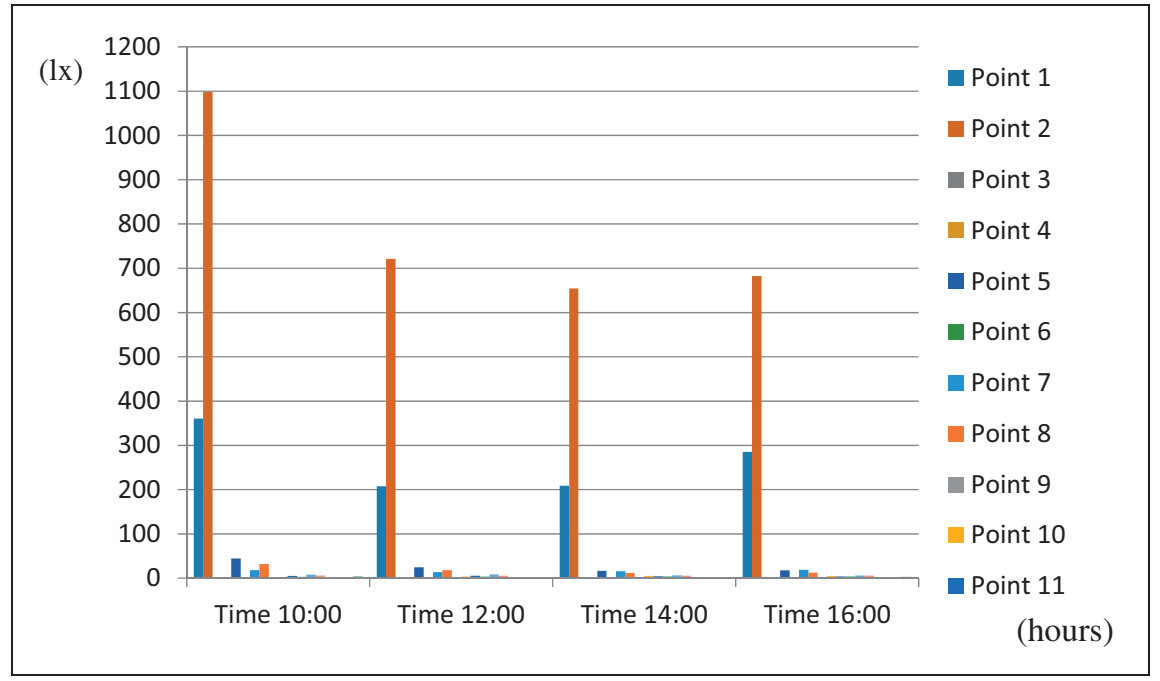

Figure 4. Illuminance level diagram in lux (lx) - Clear-sky condition.

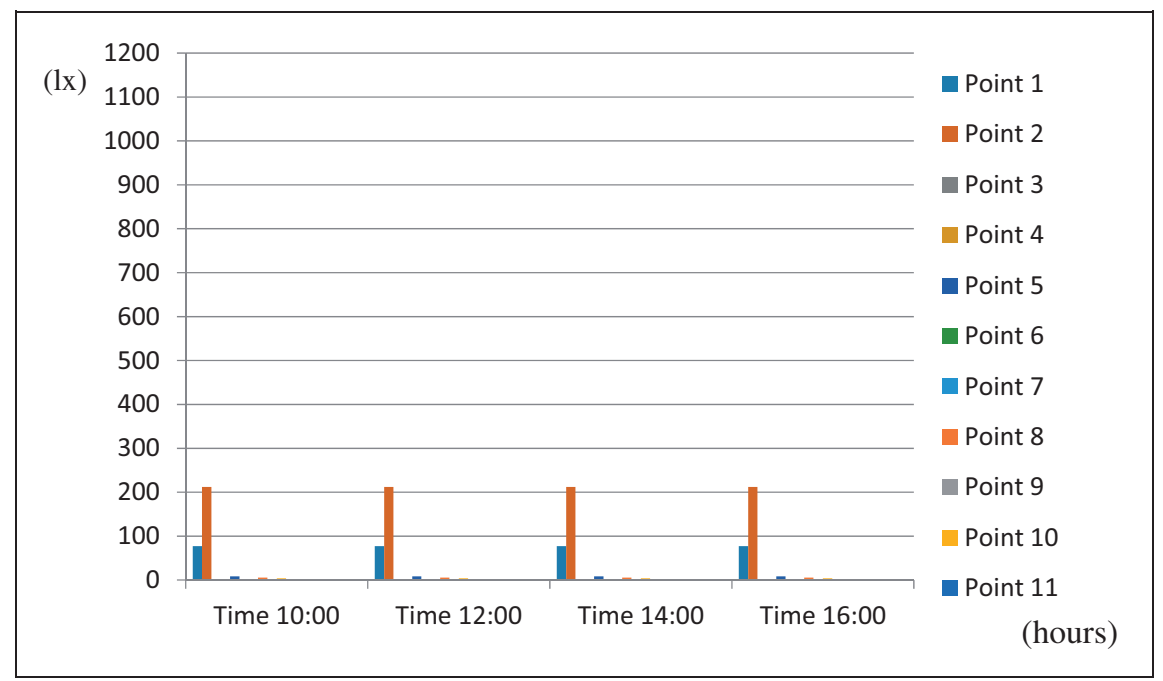

Figure 5. Illuminance level diagram in lux (lx) - Overcast-sky condition.

greatest foot-candle values. The questionnaire results show that museum visitors experienced no negative impact from the illuminance level difference, perhaps because of the artificial light design. Further, the view from and visual quality of point 1 and point 2 appeared efficient enough to satisfy visitors, so that they were not dissatisfied by the other points' lower illuminance levels. (These illuminance values were obtained when there was no artificial light in the art museum environment.)

\section{Conclusions}

There are many significant correlations among factors of visual comfort, prevention of imbalanced daylight distribution, local glare and inadequate daylight intensity in interiors. Other correlations among daylight design issues include window and skylight usage and control strategies such as excess light filtration, glare prevention, reflected light techniques and shading devices. In the statistical and simulation analyses, the authors recorded a rich data set containing illuminance measurements, illuminance pictures, and visitor answers to the detailed survey. The data set provides two essential daylight considerations as a practical guide for interested parties.

The first consideration is strongly associated with design aspects for a museum, regardless of the weather condition: museum location, window size and window distance from exhibition panels and objects. Most survey participants highlighted the link between visual environmental quality and the visual connection to the outdoors. To facilitate such a link, designers should 
acquire daylight illuminance levels for a specific site location as early as possible in the conceptual stage of the design process, during which they can determine window size and location as well as exhibition wall placement. Daylight availability can dramatically change from point to point even over a short distance (in this study it changed from P2 (1097.91 lux) to P18 (4.30 lux) in a clear-sky condition from over 16.5 metres). Therefore, designers should incorporate proper façade design strategies at the beginning of the project to support higher satisfaction levels with visual comfort. In this museum study, windows and skylights are very strongly correlated with each other for both weather conditions in terms of visitor importance levels (0.903 for clear-sky and 0.907 for overcast sky).

The second essential consideration is glare prevention from openings such as windows and skylights, a crucial aspect in visual comfort issues. Glare from neighbouring building surfaces or location settings (e.g. water) should also be considered for effective design. In the current study, as the windows of the museum's exhibition space face the sea, shading systems were found to be effective in supporting visitors' visual comfort and satisfaction with the daylight environment. Preventing glare from windows and neighbouring building structures were also important satisfaction criteria for participants. As a summary of these two key considerations, providing visitors with effective control strategies statistically relates to an increase in visit satisfaction. The unstructured part of the survey also supports this importance of the daylight experience for visitors.

There are some limitations of the study. This is just one museum. Further studies should be repeated in other locations, perhaps one not beside water. Since no one over 65 was a participant, nor no children, age could be a limitation factor. With the goals of sustainability, energy efficiency and improved well-being, the authors hope these findings are used by museum designers to enhance museum design and increase visitor satisfaction.

\section{Authors' contribution}

All authors contributed equally in the preparation of this manuscript.

\section{Declaration of conflicting interests}

The author(s) declared no potential conflicts of interest with respect to the research, authorship and/or publication of this article.

\section{Funding}

The author(s) received no financial support for the research, authorship and/or publication of this article.

\section{References}

1. Fadzil SF and Sia SJ. Sunlight control and daylight distribution analysis: the KOMTAR case study. Build Environ 2003; 39: 713-717.

2. Konis K. Evaluating daylighting effectiveness and occupant visual comfort in a side-lit open-plan office building in San Francisco, California. Build Environ 2012; 59: 662-677.

3. Nikpour M, Kandar MZ and Mosavi E. Investigating daylight quality using self-shading strategy in energy commission building in Malaysia. Indoor Built Environ 2012; 22: 822-835.

4. Kim CS and Chung SJ. Daylighting simulation as an architectural design process in museums installed with toplights. Build Environ 2010; 46: 210-222.

5. Anthierens C, Leclercq M, Bideaux E and Flambard L. A smart sensor to evaluate visual comfort of daylight into buildings. Lyon: Taylor and Francis, 2012.

6. Flynn JE, Spencer TJ, Martyniuk $\mathrm{O}$ and Hendrick C. Interim study of procedures for investigating the effect of light on impression and behaviour. J Illum Eng Soc 1973; 3: 87-94.

7. Flynn JE, Hendrick C, Spencer TJ and Martyniuk O. A guide to methodology procedures for measuring subjective impressions in lighting. J Illum Eng Soc 1979; 8: 95-110.

8. Cheung HD and Chung TM. A study on subjective preference to daylit residential indoor environment using conjoint analysis. $\mathrm{PhD}$ Thesis, Hong Kong, The Hong Kong Polytechnic University, 2007.

9. Boyce P, Hunter $\mathrm{C}$ and Howlett O. The benefits of daylight through windows. MSc Thesis, Troy, New York, Rensselaer Polytechnic Institute, 2003.

10. Butler DL and Biner PM. Effects of seating on window preferences and factors associated with those preferences. Environ Behav 1989; 5: 17-31.

11. Kilic DK and Hasirci D. Daylighting concepts for university libraries and their influences on users' satisfaction. J Acad Libr 2011; 37: 471-479.

12. Melendez JM, Mecklenburg MF and Domenechcarbo MT. An evaluation of daylight distribution as an initial preventive conservation measure at Smithsonian Institution Museums, Washington DC, USA. J Cult Heritage 2010; 12: 54-64.

13. Heerwagen $\mathbf{J}$ and Heerwagen D. Lighting and psychological comfort. Environ Behav 1986; 16: 695-721.

14. Veitch JA and Robert G. End user's knowledge, beliefs and preferences for lighting. J Inter Des 1993; 19: 15-26.

15. Ornetzeder M, Wicher M and Suschek BJ. User satisfaction and well-being in energy efficient office buildings: evidence from cutting-edge projects in Austria. Energy Build 2016; 118: 18-26.

16. Steemers K. Enhancing energy efficiency and visual quality. Renew Energy 1994; 5: 950-958.

17. Kim CS and Kim KS. Daylighting performance in the exhibition space of museum with various shapes of toplight in the conditions of clear sky with sun. J Archit Inst Korea 2006; 22: 309-316.

18. Mundo-Hernández J, Valerdi-Nochebuena MC and Sosa-Oliver J. Post-occupancy evaluation of a restored industrial building: a contemporary art and design gallery in Mexico. Front Archit Res 2015; 4: 330-340.

19. Brida JG, Disegna M and Vachkova T. Visitor satisfaction at the museum: Italian versus foreign visitors. Preliminary Commun 2013; 61: 167-186.

20. Cannon-Brookes S. Lighting: daylight in historic buildings/new museums: some practical considerations. Museum Manage Curatorship 1994; 13: 100-104.

21. Escuyer S and Fontoynont M. Lighting controls: a field study on office workers' reactions. Light Res Technol 2001; 33: 94-95. 
22. Paul WL and Taylor PA. A comparison of occupant comfort and satisfaction between a green building and a conventional building. Build Environ 2008; 43: 1858-1870.

23. Sarbu I and Sebarchievici C. Aspects of indoor environmental quality assessment in buildings. Energy Build 2013; 60: 410-419.

24. Bougdah H and Sharples S. Environment, technology and sustainability. New York, United States of America, New York: Taylor \& Francis, 2010.

25. Sutter Y, Dumortier D and Fontoynont M. The use of shading systems in VDU task offices: a pilot study. Energy Build 2006; 38 : 780-789.

26. Hopkinson RG. Glare from windows. Constr Res Dev 1970; 2 : 98-105.

27. Osterhaus WE and Bailey IL. Large area glare sources and their effect on discomfort and visual performance at computer workstations. Report LBL-35037 UC-350. Berkeley, California, California, USA: Lawrence Berkeley National Laboratory, 1992.

28. Wienold $\mathbf{J}$ and Christoffersen J. Evaluation methods and development of a new glare prediction model for daylight environments with the use of CCD cameras. Energy Build 2006; 38: 743-757.

\section{Appendix 1. Survey}

\section{A. Demographics}

Male Female

1 Gender

2 Age group

$2+$

1

$2+$

1

/week

/week /month /month

Less

3 Visit frequency

High University Graduate Post Graduate
Hassan AS and Arab Y. Reliability of computer simulation on illuminance level of pendentive dome mosque in comparison with field data collection. Modern Appl Sci 2014; 8: 183-192.

Chengalur SN, Rodgers SH and Bernard TE. Kodak's ergonomic design for people at work. Hoboken: John Wiley and Sons, 2004. Anergy Build 2006; 38: 905-913. Polo JF. The Istanbul modern art museum: an urban regeneration project. Eur Plann Stud 2015; 23: 1511-1528.

atilizing daylight. In. Schittich C Solar architecture: strategies visions and concept. Berlin: (a) building design. Energy Build 2006; 38 824-835.
4 Education level
School 
B. Overall Ranking - Below are listed components of daylight and daylight design. Please rate the importance levels of these components based on your experiences and visual comfort within Istanbul Modern Art Museum.

$$
\begin{array}{lllll}
\text { 1.Not } & \text { 2.Slightly } & \text { 3.Neutral } & \text { 4.Effective } & \text { 5.Very } \\
\text { Effective } & \text { Effective }
\end{array} \quad \text { Effive }
$$

1. Daylight availability in museum interior space

2. Controlled daylight intake

3. Size and division of windows

4 - Visual connections to outdoors

5 -Prevention of glare from windows

6 - Prevention of glare from sea and neighbouring building structures

7- Colour rendering of surfaces

8 - Filtration of excess light exposure (UV, Infrared...)

9 -Homogeneous distribution of daylight on wall surfaces

10 - Thermal comfort conditions depending on daylight 
C. Importance Level - Below are listed components of daylight and daylight design. Please rate the importance level of each component for an art museum in general. Please consider that artificial light also exists in museum interiors.

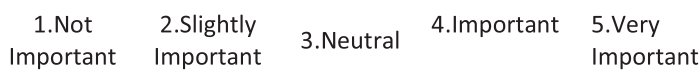

C Windows

1

2 Skylights

3 Shading systems (interior \& exterior)

4 Reflected light techniques (Light shelves)

5 Visual comfort for daylight

a)

$$
\begin{aligned}
& \text { Prevention of } \\
& \text { imbalanced } \\
& \text { daylight }
\end{aligned}
$$
distribution

b)

Prevention of local glare

c) Prevention of high contrast illuminated

d)

Prevention of inadequate daylight intensity in interior space

6 Visual connection to outdoors

7 Neighbouring building surfaces and visual obstructions

8 Energy conservation and sustainability

$x$ Anything else you want to add?? 


\section{Appendix 2. Correlation tables}

Table 4. Pearson's correlation for questionnaire part B - clear sky condition.

\begin{tabular}{|c|c|c|c|c|c|}
\hline Correlation matrix & $\begin{array}{l}\text { Control systems } \\
\text { of daylight intake }\end{array}$ & $\begin{array}{l}\text { Prevention of } \\
\text { glare from } \\
\text { windows }\end{array}$ & $\begin{array}{l}\text { Prevention of } \\
\text { glare from neighbouring } \\
\text { building structures }\end{array}$ & $\begin{array}{l}\text { Filtration of } \\
\text { excess light } \\
\text { exposure }\end{array}$ & $\begin{array}{l}\text { Overall } \\
\text { satisfaction }\end{array}$ \\
\hline \multicolumn{6}{|l|}{$\begin{array}{l}\text { Control systems of } \\
\text { daylight intake }\end{array}$} \\
\hline Pearson correlation & 1 & & & & \\
\hline \multicolumn{6}{|l|}{ Sig. (two-tailed) } \\
\hline $\mathrm{N}$ & 120 & & & & \\
\hline \multicolumn{6}{|c|}{$\begin{array}{l}\text { Prevention of glare from } \\
\text { windows }\end{array}$} \\
\hline Pearson correlation & $0.493^{\mathrm{a}}$ & 1 & & & \\
\hline Sig. (two-tailed) & 0.000 & & & & \\
\hline $\mathrm{N}$ & 120 & 120 & & & \\
\hline \multicolumn{6}{|c|}{$\begin{array}{l}\text { Prevention of glare from } \\
\text { neighbouring building } \\
\text { structures }\end{array}$} \\
\hline Pearson correlation & $0.482^{\mathrm{a}}$ & $0.808^{\mathrm{a}}$ & 1 & & \\
\hline Sig. (two-tailed) & 0.000 & 0.000 & & & \\
\hline $\mathrm{N}$ & 120 & 120 & 120 & & \\
\hline \multicolumn{6}{|c|}{$\begin{array}{l}\text { Filtration of excess light } \\
\text { exposure }\end{array}$} \\
\hline Pearson correlation & $0.366^{\mathrm{a}}$ & $0.496^{\mathrm{a}}$ & $0.451^{\mathrm{a}}$ & 1 & \\
\hline Sig. (two-tailed) & 0.000 & 0.000 & 0.000 & & \\
\hline $\mathrm{N}$ & 120 & 120 & 120 & 120 & \\
\hline \multicolumn{6}{|l|}{ Overall satisfaction } \\
\hline Pearson correlation & $0.528^{\mathrm{a}}$ & $0.428^{\mathrm{a}}$ & $0.422^{\mathrm{a}}$ & $0.446^{\mathrm{a}}$ & 1 \\
\hline Sig. (two-tailed) & 0.000 & 0.000 & 0.000 & 0.000 & \\
\hline $\mathrm{N}$ & 120 & 120 & 120 & 120 & 120 \\
\hline
\end{tabular}

${ }^{a}$ Correlation is significant at the 0.01 level (two-tailed).

Bold numbers represents the moderate and strong correlation levels (level $<0.399$ is low correlation level, whereas $0.400<$ level $<0.599$ is moderate correlation level, and level $>0.600$ is strong correlation level).

Table 5. Pearson's correlation for questionnaire part B - clear sky condition.

\begin{tabular}{llllll}
\hline Correlation matrix & $\begin{array}{l}\text { Daylight } \\
\text { availability }\end{array}$ & $\begin{array}{l}\text { Size and divisions } \\
\text { windows }\end{array}$ & $\begin{array}{l}\text { Direct sun } \\
\text { penetration }\end{array}$ & $\begin{array}{l}\text { Colour } \\
\text { rendering } \\
\text { of surfaces }\end{array}$ & $\begin{array}{l}\text { Overall } \\
\text { satisfaction }\end{array}$ \\
\hline $\begin{array}{l}\text { Daylight availability } \\
\text { Pearson correlation } \\
\begin{array}{l}\text { Sig. (two-tailed) } \\
\mathrm{N}\end{array}\end{array}$ & 1 & & & \\
$\begin{array}{l}\text { Size and divisions of windows } \\
\text { Pearson correlation }\end{array}$ & 120 & & & \\
$\begin{array}{l}\text { Sig. (two-tailed) } \\
\mathrm{N}\end{array}$ & $\mathbf{0 . 5 7 0 ^ { \mathrm { a } }}$ & 1 & & \\
$\begin{array}{l}\text { Direct sun penetration } \\
\text { Pearson correlation }\end{array}$ & 120 & 120 & & \\
\hline & $\mathbf{0 . 6 0 0}$ & & & \\
\hline
\end{tabular}


Table 5. Continued

\begin{tabular}{|c|c|c|c|c|c|}
\hline Correlation matrix & $\begin{array}{l}\text { Daylight } \\
\text { availability }\end{array}$ & $\begin{array}{l}\text { Size and divisions } \\
\text { windows }\end{array}$ & $\begin{array}{l}\text { Direct sun } \\
\text { penetration }\end{array}$ & $\begin{array}{l}\text { Colour } \\
\text { rendering } \\
\text { of surfaces }\end{array}$ & $\begin{array}{l}\text { Overall } \\
\text { satisfaction }\end{array}$ \\
\hline Sig. (two-tailed) & 0.000 & 0.000 & & & \\
\hline $\mathrm{N}$ & 120 & 120 & 120 & & \\
\hline \multicolumn{6}{|c|}{ Colour rendering of surfaces } \\
\hline Pearson correlation & $0.348^{\mathrm{a}}$ & $0.318^{\mathrm{a}}$ & $0.413^{\mathrm{a}}$ & 1 & \\
\hline Sig. (two-tailed) & 0.000 & 0.000 & 0.000 & & \\
\hline $\mathrm{N}$ & 120 & 120 & 120 & 120 & \\
\hline \multicolumn{6}{|l|}{ Overall satisfaction } \\
\hline Pearson correlation & $0.613^{\mathrm{a}}$ & $0.396^{\mathrm{a}}$ & $0.623^{\mathrm{a}}$ & $0.506^{\mathrm{a}}$ & 1 \\
\hline Sig. (two-tailed) & 0.000 & 0.000 & 0.000 & 0.000 & \\
\hline $\mathrm{N}$ & 120 & 120 & 120 & 120 & 120 \\
\hline
\end{tabular}

${ }^{\mathrm{a}}$ Correlation is significant at the 0.01 level (two-tailed).

Bold numbers represents the moderate and strong correlation levels (level $<0.399$ is low correlation level, whereas $0.400<$ level $<0.599$ is moderate correlation level, and level $>0.600$ is strong correlation level).

Table 6. Pearson's correlation for questionnaire part B - overcast sky condition.

\begin{tabular}{|c|c|c|c|c|c|}
\hline Correlation matrix & $\begin{array}{l}\text { Control systems } \\
\text { of daylight intake }\end{array}$ & $\begin{array}{l}\text { Prevention } \\
\text { of glare } \\
\text { from windows }\end{array}$ & $\begin{array}{l}\text { Prevention of } \\
\text { glare from } \\
\text { neighbouring } \\
\text { building structures }\end{array}$ & $\begin{array}{l}\text { Filtration of } \\
\text { excess light } \\
\text { exposure }\end{array}$ & $\begin{array}{l}\text { Overall } \\
\text { satisfaction }\end{array}$ \\
\hline \multicolumn{6}{|l|}{$\begin{array}{l}\text { Control systems of } \\
\text { daylight intake }\end{array}$} \\
\hline Pearson correlation & 1 & & & & \\
\hline \multicolumn{6}{|l|}{ Sig. (two-tailed) } \\
\hline $\mathrm{N}$ & 120 & & & & \\
\hline \multicolumn{6}{|c|}{$\begin{array}{l}\text { Prevention of glare from } \\
\text { windows }\end{array}$} \\
\hline Pearson correlation & $0.527^{\mathrm{a}}$ & 1 & & & \\
\hline Sig. (two-tailed) & 0.000 & & & & \\
\hline $\mathrm{N}$ & 120 & 120 & & & \\
\hline \multicolumn{6}{|l|}{$\begin{array}{l}\text { Prevention of Glare } \\
\text { from neighbouring } \\
\text { building structures }\end{array}$} \\
\hline Pearson correlation & $0.570^{\mathrm{a}}$ & $0.846^{\mathrm{a}}$ & 1 & & \\
\hline Sig. (two-tailed) & 0.000 & 0.000 & & & \\
\hline $\mathrm{N}$ & 120 & 120 & 120 & & \\
\hline \multicolumn{6}{|c|}{$\begin{array}{l}\text { Filtration of excess light } \\
\text { exposure }\end{array}$} \\
\hline Pearson correlation & $0.450^{\mathrm{a}}$ & $0.417^{\mathrm{a}}$ & $0.358^{\mathrm{a}}$ & 1 & \\
\hline Sig. (two-tailed) & 0.000 & 0.000 & 0.000 & & \\
\hline $\mathrm{N}$ & 120 & 120 & 120 & 120 & \\
\hline \multicolumn{6}{|l|}{ Overall satisfaction } \\
\hline Pearson correlation & $0.428^{\mathrm{a}}$ & $0.389^{\mathrm{a}}$ & $0.389^{\mathrm{a}}$ & $0.509^{\mathrm{a}}$ & 1 \\
\hline Sig. (two-tailed) & 0.000 & 0.000 & 0.000 & 0.000 & \\
\hline $\mathrm{N}$ & 120 & 120 & 120 & 120 & 120 \\
\hline
\end{tabular}

${ }^{\mathrm{a}}$ Correlation is significant at the 0.01 level (2-tailed).

Bold numbers represents the moderate and strong correlation levels (level $<0.399$ is low correlation level, whereas $0.400<$ level $<0.599$ is moderate correlation level, and level $>0.600$ is strong correlation level). 
Table 7. Pearson's correlation for questionnaire part B - overcast-sky condition.

\begin{tabular}{|c|c|c|c|c|c|}
\hline Correlation Matrix & $\begin{array}{l}\text { Daylight } \\
\text { availability }\end{array}$ & $\begin{array}{l}\text { Size and divisions } \\
\text { of windows }\end{array}$ & $\begin{array}{l}\text { Direct sun } \\
\text { penetration }\end{array}$ & $\begin{array}{l}\text { Colour } \\
\text { rendering of } \\
\text { surfaces }\end{array}$ & $\begin{array}{l}\text { Overall } \\
\text { satisfaction }\end{array}$ \\
\hline \multicolumn{6}{|l|}{ Daylight availability } \\
\hline Pearson correlation & 1 & & & & \\
\hline \multicolumn{6}{|l|}{ Sig. (two-tailed) } \\
\hline $\mathrm{N}$ & 120 & & & & \\
\hline \multicolumn{6}{|l|}{ Size and divisions of windows } \\
\hline Pearson correlation & $0.509^{\mathrm{a}}$ & 1 & & & \\
\hline Sig. (two-tailed) & 0.000 & & & & \\
\hline $\mathrm{N}$ & 120 & 120 & & & \\
\hline \multicolumn{6}{|l|}{ Direct sun penetration } \\
\hline Pearson correlation & $0.724^{\mathrm{a}}$ & $0.441^{\mathrm{a}}$ & 1 & & \\
\hline Sig. (two-tailed) & 0.000 & 0.000 & & & \\
\hline $\mathrm{N}$ & 120 & 120 & 120 & & \\
\hline Colour rendering of surfaces & $0.323^{\mathrm{a}}$ & $0.188^{\mathrm{a}}$ & $0.174^{\mathrm{a}}$ & 1 & \\
\hline Pearson Correlation & 0.000 & 0.001 & 0.000 & & \\
\hline \multicolumn{6}{|l|}{ Sig. (two-tailed) } \\
\hline $\mathrm{N}$ & 120 & 120 & 120 & 120 & \\
\hline \multicolumn{6}{|l|}{ Overall satisfaction } \\
\hline Pearson correlation & $0.292^{\mathrm{a}}$ & $0.243^{\mathrm{a}}$ & $0.344^{\mathrm{a}}$ & $0.523^{\mathrm{a}}$ & 1 \\
\hline Sig. (two-tailed) & 0.000 & 0.000 & 0.000 & 0.000 & \\
\hline $\mathrm{N}$ & 120 & 102 & 120 & 120 & 120 \\
\hline
\end{tabular}

${ }^{\mathrm{a}}$ Correlation is significant at the 0.01 level (2-tailed).

Bold numbers represents the moderate and strong correlation levels (level $<0.399$ is low correlation level, whereas $0.400<1$ level $<0.599$ is moderate correlation level, and level $>0.600$ is strong correlation level). 